\title{
Forced Expiratory Flow at 50 Percent Forced Vital Capacity
}

National Cancer Institute

\section{Source}

National Cancer Institute. Forced Expiratory Flow at 50 Percent Forced Vital Capacity. NCI Thesaurus. Code C139253.

The mean forced expiratory flow rate at $50 \%$ of the forced vital capacity. 